Исайкина Елена Дмитриевна, кандидат исторических наук, доцент кафедры документоведения e-mail: isaykina.od@ukr.net

ГВУЗ «Переяслав-Хмельницкий государственный педагогический университет имени Григория Сковороды» ул. Сухомлинского 30, г. Переяслав, Киевская обл., Украина, 08401

\title{
DATA ON AUTHORS
}

Zlenko Alla, candidate of historical sciences, associate professor of scientific discipline of documentation Pereyaslav-Khmenytsky Hryhoriy Skovoroda Pedagogical University

30, Sukhomlynsky Str., Pereyaslav, Kyiv region, Ukraine, 08401

e-mail: zlenko.am@ukr.net

Isaikina Olena, candidate of historical sciences, associate professor of scientific discipline of documentation Pereyaslav-Khmenytsky Hryhoriy Skovoroda Pedagogical University

30, Sukhomlynsky Str., Pereyaslav, Kyiv region, Ukraine, 08401

e-mail: isaykina.od@ukr.net

\section{ДЕРЖАВНА ПІДТРИМКА МАЛОГО ТА СЕРЕДНЬОГО БІЗНЕСУ В СУЧАСНИХ УМОВАХ}

Предметом дослідження є теоретичні й практичні аспекти проблем, що постають у сфрері державної підтримки малого та середнього підприємництва в Україні.

Метою стаmmi $\epsilon$ виявлення основних деструктивних чинників розвитку середніх та малих підприємств та встановлення шляхів їх подолання.

Методологічною основою статmі є загальнонаукові та спеціальні методи наукового пізнання, такі як діалектичний метод, аналіз, групування даних, проблемно-цільовий підхід.

Результати роботи. У статmі розглядається особлива роль середнього та малого підприємництва в частині фрормування ВВП, створення робочих місць, покращення демографічної ситуації. Наголошується, що значна частка підприємств або фрункціонує в тіньовому секторі, або не вживає заходів щодо підвищення прибутковості. Висунуто гіпотезу, що вагомою причиною такого стану є недосконала державна підтримка підприємств малого та середнього бізнесу. Передусім, це велике податкове навантаження, низькі заробітні плати у секторі, нестабільне законодавство. Наголошується, що додатковим викликом стала і всесвітня пандемія коронавірусу: через карантинні заходи більшість підприємств малого та середнього бізнесу опинились на межі виживання.

Галузь застосування результатів. Матеріали, результати й висновки статті можуть бути використані у діяльності різноманітних громадських організацій, місцевих органів самоврядування як аналітичне підгрунтя звернень щодо необхідності державної підтримки середнього та малого підприємництва, в підготовці фрахівців в середніх та вищих навчальних закладах.

Висновки. Малий та середній бізнес виступає стимулятором розвитку економіки. Він забезпечує вагому частку у структурі ВВП, сприяє розвитку середнього класу, здійснює позитивний вплив на демографрічні показники. Можливість та здатність малого та середнього підприємництва до розвитку навіть за складних політичних та економічних умов доводить, що саме ці суб'єкти господарювання $\epsilon$ основою для підтримки економіки в складні часи.

Таким чином, пріоритетним завданням уряду має стати створення сприятливого середовища для ведення бізнесу та розвитку малого та середнього підприємництва. Для цього повинні реально запрацювати програми підтримки: інформаційного характеру, фінансового забезпечення, соціального супроводу. Активна i цілеспрямована підтримка розвитку суб'єктів малого та середнього підприємництва сприяє зростанню ВВП та створенню нових робочих місць.

Ключові слова: середні та малі підприємства, розвиток, державна підтримка.

\section{ГОСУДАРСТВЕННАЯ ПОДДЕРЖКА МАЛОГО И СРЕДНЕГО БИЗНЕСА В СОВРЕМЕННЫХ УСЛОВИЯХ}

Нестерова С. В. Копча В. B. Михальчинець Г. Т.

Предметом исследования являются теоретические и практические аспекты проблем, стоящих в сфрере государственной поддержки малого и среднего предпринимательства в Украине. 
Целью статьи является выявление основных деструктивных фракторов развития средних и малых предприятий и установление путей их преодоления.

Методологической основой статьи являются общенаучные и специальные методы научного познания, такие как диалектический метод, анализ, группировка данных, проблемно-целевой подход.

Результаты работы. В статье рассматривается особая роль среднего и малого предпринимательства в части формирования ВВП, создание рабочих мест, улучшение демографической ситуации. Отмечается, что значительная часть предприятий или работает в теневом секторе, либо не принимает меры по повышению прибыльности. Выдвинута гипотеза, что весомой причиной такого состояния является несовершенная государственная поддержка предприятий малого и среднего бизнеса. Прежде всего, это большая налоговая нагрузка, низкие заработные платы в секторе, нестабильное законодательство. Отмечается, что дополнительным вызовом стала и всемирная пандемия коронавируса: через карантинные мероприятия большинство предприятий малого и среднего бизнеса оказались на грани выживания.

Область применения результатов. Материалы, результаты и выводы статьи могут быть использованы в деятельности различных общественных организаций, местных органов самоуправления как аналитическое основание обращений о необходимости государственной поддержки среднего и малого предпринимательства, в подготовке специалистов в средних и высших учебных заведениях.

Выводы. Малый и средний бизнес выступает стимулятором развития экономики. Он обеспечивает весомую долю в структуре ВВП, способствует развитию среднего класса, оказывает положительное влияние на демографические показатели. Возможность и способность малого и среднего предпринимательства к развитию даже в сложных политических и экономических условий доказывает, что именно эти субъекты хозяйствования является основой для поддержки экономики в сложные времена.

Таким образом, приоритетной задачей правительства должно стать создание благоприятной среды для ведения бизнеса и развития малого и среднего предпринимательства. Для этого должны реально заработать программы поддержки: информационного характера, фринансового обеспечения, социального сопровождения. Активная и целенаправленная поддержка развития субъектов малого и среднего предпринимательства способствует росту ВВП и созданию новых рабочих мест.

Ключевые слова: средние и малые предприятия, развитие, государственная поддержка.

\section{STATE SUPPORT FOR SMALL AND MEDIUM-SIZED BUSINESSES IN MODERN CONDITIONS}

Nesterova Svitlana, Kopcha Veronika, Myhalchinets Halyna

The subject of the research. The study focuses on the theoretical and practical aspects of the problems facing State support for small and medium-sized enterprises in Ukraine.

The purpose of the article is to identify the main destructive factors in the development of medium and small enterprises and to identify ways to overcome them.

The methodological basis of the article is general scientific and special methods of scientific knowledge, such as dialectical method, analysis, grouping of data, problem-oriented approach.

Results of work. The article discusses the special role of medium-and small-scale enterprises in generating GDP, creating jobs and improving the demographic situation. It is noted that a significant proportion of enterprises either operate in the shadow sector or do not take measures to improve profitability. It has been hypothesized that an important reason for this state of affairs is imperfect state support for small and medium-sized enterprises. First of all, there is a heavy tax burden, low wages in the sector, unstable legislation. The worldwide coronavirus pandemic has also been noted as an additional challenge, with most small and medium-sized businesses on the verge of survival through quarantine activities.

The field of application of results. The materials, results and conclusions of the article may be used in the activities of various public organizations and local self-government bodies as an analytical basis for appeals about the need for State support for small and medium-sized enterprises, Training of specialists in secondary and higher education.

Conclusions. Small and medium-sized businesses are the driving force behind the economy. It provides a large share of GDP, promotes the development of the middle class and has a positive impact on demographic indicators. The opportunity and ability of small and medium-sized enterprises to develop, even under difficult political and economic conditions, proves that it is these entities that support the economy in difficult times.

Creating an enabling environment for doing business and developing small and medium-sized enterprises should therefore be a priority for the Government. To this end, support programs must be put in place: infotrmation, financial security and social support. Active and targeted support for the development of small and medium-sized enterprises contributes to the growth of GDP and the creation of new jobs.

Key words: medium and small enterprises, development, state support.

JEL Classification: G31, Q12-13

Постановка проблеми. Відомим $€$ факт, що малий та середній бізнес є стимулятором розвитку економіки та виступає важливим елементом, на який спирається вся господарська система країни. Він виступає провідним сектором, який в більшій мірі визначає темпи економічного зростання країни, стан зайнятості населення, становить вагому частку у структурі ВВП. 
Аналіз останніх досліджень і публікацій. Державна підтримка розвитку малого та середнього бізнесу В Україні розглядалась українськими вченими Н. С. Поповенко, О.В. Ганенко, В.В.Дергачовою, Я. О. Колешнею, Д. Андреєвим та ін. Вчені аналізували як механізми підтримки, так і чинники деструктивного управління даним сектором національної економіки. Проте фракти низької прибутковості підприємств, пандемічний виклик потребують актуалізації даної проблеми.

Метою статті $\epsilon$ виявлення основних деструктивних чинників розвитку середніх та малих підприємств та встановлення шляхів їх подолання.

Виклад основного матеріалу дослідження. Перспективами, що відкриває для країни розвиток малого та середнього бізнесу, $є$ формування середнього класу, зростання частки економічно активного населення, створення нових робочих місць, створення конкурентного середовища, поліпшення взаємозв'язку між різними секторами економіки, розроблення нововведень [3].

Згідно даних Конференції Об'єднаних Націй із торгівлі та розвитку, у переважній більшості країн на суб'єктів малого та середнього бізнесу припадає близько 90\%, а іноді 95\% питомої ваги із загальної кількості суб'єктів підприємництва. У країнах ЄС суб'єкти МСП становлять 99,8\%, у США - понад 90\%, в Японії - 99\% [1].

На сьогодні Україна не відстає від своїх «сусідів» - країн ЄС. Тоді як, у зв'язку із кризовими явищами, послабленням економіки та падінням гривні у 2014 році, спостерігалось різку скорочення численності великих підприємств, чисельність малих та середніх - продовжила зростати. Нині ця частка становить близько $99 \%$ [3]. Це свідчить про можливість та здатність малого та середнього підприємництва до розвитку навіть за складних політичних та економічних умов та вкотре доводить те, що саме ці суб'єкти господарювання $\epsilon$ основою для підтримки нашої економіки в складні часи.

Проте, незважаючи на високу здатність до виживання і розвитку в складних умовах господарювання, згідно статистичних даних, позитивні фрінансові результати до оподаткування мають лише $62-65 \%$ підприємств, тобто малий та середній бізнес на $35 \%$ є збитковим. Причинами таких результатів $є$ :

1) нестабільна законодавча база, яка постійно змінюється з приходом нової влади;

2) невиважена державна політика та програма підтримки малого та середнього бізнесу;

3) складність доступу до фінансових ресурсів, через що ускладнюється можливість розширення діяльності чи модернізації, а це в свою чергу впливає на наявність застарілої матеріально-технічної бази;

4) постійне збільшення експорту сировини за кордон, через що гальмується стимулювання виробничих галузей, роблячи їх не перспективними для малого та середнього бізнесу, більша частина якого - це підприємства, зайняті у сфрері торгівлі;

5) високий рівень податкового навантаження на малі та середні суб'єкти господарювання, що стимулює розвиток тіньової економіки [4];

6) корупція в органах влади та наявність багатьох бюрократичних перепон для заснування і ведення бізнесу.

Усі ці перепони можуть бути вирішені з допомогою держави, яка активно бере участь у господарських відносинах, а не лише споглядає за ними.

Згідно даних Державної служби статистики України, станом на початок 2019 року, мале та середнє підприємництво виробило 91,9\% загального обсягу виробництва продукції (робіт, послуг) у цілому по Україні, що свідчить про більш ефективне його функціонування порівняно з великим. А кількість зайнятих працівників на малих та середніх підприємствах, яких налічується близько 1,84 млн., становить 9,99 млн. осіб, а це - 86,4\% від загальної кількості працівників приватного сектору економіки і ця тенденція з кожним роком збільшується (Табл. 1) [7].

Таблиця 1. Кількість зайнятих працівників на підприємствах за їх розмірами за 2014-2018 рр., тис. ос.

\begin{tabular}{|c|c|c|c|c|c|c|c|c|c|c|}
\hline & \multicolumn{2}{|c|}{2014} & \multicolumn{2}{|c|}{2015} & \multicolumn{2}{|c|}{2016} & \multicolumn{2}{|c|}{2017} & \multicolumn{2}{|c|}{2018} \\
\hline & $\mid$\begin{tabular}{|} 
Кількість \\
зайнятих
\end{tabular} & $\begin{array}{c}\text { у \% до } \\
\text { загальної } \\
\text { кількості } \\
\text { зайнятих } \\
\end{array}$ & $\begin{array}{l}\text { Кількість } \\
\text { зайнятих }\end{array}$ & $\begin{array}{c}\text { у \% до } \\
\text { загальної } \\
\text { кількості } \\
\text { зайнятих } \\
\end{array}$ & $\begin{array}{l}\text { Кількість } \\
\text { зайнятих }\end{array}$ & $\begin{array}{c}\text { у \% до } \\
\text { загальної } \\
\text { кількості } \\
\text { зайнятих } \\
\end{array}$ & $\begin{array}{l}\text { Кількість } \\
\text { зайнятих }\end{array}$ & $\begin{array}{c}\text { у \% до } \\
\text { загальної } \\
\text { кількості } \\
\text { зайнятих } \\
\end{array}$ & $\begin{array}{l}\text { Кількість } \\
\text { зайнятих }\end{array}$ & $\begin{array}{c}\text { у \% до } \\
\text { загальної } \\
\text { кількості } \\
\text { зайнятих }\end{array}$ \\
\hline $\begin{array}{l}\text { Великі } \\
\text { підприємства }\end{array}$ & 1915094 & 16,3 & 1708592 & 15,5 & 1586582 & 14,5 & 1560900 & 14,2 & 1574301 & 13,6 \\
\hline $\begin{array}{l}\text { Середні, малі та } \\
\text { мікропідприємства }\end{array}$ & 9858513 & 83,7 & 9349971 & 84,5 & 9336497 & 85,5 & 9454983 & 85,8 & 9991097 & 86,4 \\
\hline Всього осіб & \multicolumn{2}{|c|}{11773607} & \multicolumn{2}{|c|}{11058563} & \multicolumn{2}{|c|}{10923079} & \multicolumn{2}{|c|}{11015883} & \multicolumn{2}{|c|}{11565398} \\
\hline
\end{tabular}

Створено авторами на основі джерела [3].

Це доволі оптимістичні цифри, які свідчать про зацікавленість населення таким видом зайнятості, оскільки ним можуть займатися особи з обмеженою формальною освітою, які набувають свою кваліфікацію на робочому місці.

Проблема постає в оплаті праці. Якщо на великих підприємствах середня заробітна плата в місяць складає близько 14 тис. грн., то на середніх підприємствах цей показник 9,5 тис. грн., а на дрібних підприємствах лише 6,5 тис. грн. [3]. Така різниця полягає в тому, що на великих підприємствах заробітну плату платять офіційно, і тому вона вища, а на середніх і малих підприємствах практикують виплату заробітної плати в «конверті», тому вона, згідно офіційних даних $є$ нижчою. 
Причиною цього являється непосильне податкове навантаження для підприємств. А особливо відчутно і болісно це позначається на малих підприємствах, де у вартості кінцевого продукту закладена висока частка з оплати праці (показник може сягати 30-50\%). В кінцевому рахунку ці суб'єкти господарювання мають податкову навантаження у розмірі: $20 \%$ ПДВ, 41,5\% на весь фронд оплати праці, а в кінці року - $18 \%$ податок на прибуток і 5\% податок на дивіденди.

За часів існування незалежності України, створення сприятливого середовища для ведення бізнесу та розвитку МСП є пріоритетним завданням уряду.

Основним нормативно-правовим документом у даному напрямі $€$ ЗУ «Про розвиток та державну підтримку малого і середнього підприємництва» від 22.03.2012 р. [6].

Відповідно до цього закону, державна підтримка суб'єктів малого і середнього підприємництва та об'єктів інфраструктури підтримки МСП включає фінансову, інформаційну, консультаційну підтримку, у тому числі підтримку у сфері інновацій, науки і промислового виробництва, підтримку суб'єктів малого і середнього підприємництва, що провадять експортну діяльність, підтримку у сорері підготовки, перепідготовки і підвищення кваліфікації управлінських кадрів та кадрів ведення бізнесу.

Сьогодні основні функції щодо підтримки малого та середнього бізнесу здійснює Міністерство економічного розвитку, торгівлі та сільського господарства України. За його підтримки створено «Портал для підприємців», де вони мають можливість у відкритому доступі отримувати інформацію про зміни в законодавстві, а також про бюджетні, банківські та донорські (в тому числі закордонні) програми для розвитку бізнесу.

У 2016 р. Міністерством було презентовано «Стратегію розвитку МСП 2020», згідно якої на регіональному рівні розробляється політика та стратегії розвитку регіонів. У 2017 р. Міністерство запустило портал програми Європейського Союзу з підтримки малого та середнього бізнесу в Україні - COSME. Для України, відповідно до програми, виділено 900 млн. євро для полегшення доступу до ринку Європейського союзу та міжнародного ринку, отримання доступу до інформації щодо ведення підприємницької діяльності, навчання та стажування, а також конкурси для державних органів влади для поліпшення бізнес-клімату [2].

Так, у додатку 3, 3У «Про Державний бюджет України на 2020 рік» на виконання зобов'язань України за участь у програмі ЄС «Конкурентоспроможність підприємств малого та середнього бізнесу (COSME)» виділено 25, 2 млн. грн. [6].

Також, Верховна рада, у другому читанні проекту змін закону про Державний бюджет на 2020 рік, ухвалила спрямувати 2 млрд. грн. на нову бюджетну програму «Фонд розвитку підприємництва». Ці кошти будуть видавати в межах програми «Повертайся та залишайся», згідно якої малий бізнес зможе отримати до 1,5 млн. грн. на власний розвиток під 5-9\% річних, терміном на 5 років. Це дуже оптимістичні цифри, оскільки раніше кредити на розвиток для малого бізнесу України становили 26-28\% річних терміном на 1-5 років, тоді як у Німеччині - 4-5\% на 10 років. Максимальна сума мікрокредиту для малого бізнесу в розвинених країнах - 25 тис. євро (приблизно 750 тис. грн.) під 4-6\%, а максимальна сума кредиту для малого бізнесу України - 100 тис. грн. під 26-28\% [5].

Проте, на початку 2020 року постала глобальна проблема, яка зачепила увесь світ - поширення смертельної хвороби коронавірусу. Про початок нової економічної кризи заявила голова МВФ Крісталіна Георгієва (причиною якої стала пандемія). До того ж, на думку глави Організації економічного співробітництва та розвитку Анхель Ґурріа, коронавірус став для світової економіки більшим шоком ніж світова економічна криза 2008-2009 рр.

Обмежувальні заходи та призупинення роботи через коронавірус зменшили або взагалі припинили ділову активність багатьох підприємств та компаній світу (включаючи й українські). Розуміючи наслідки цього для економіки, деякі країни запустили програми підтримки бізнесу. На підтримку малого та середнього бізнесу уряд США спрямував 367 млрд. дол., Великобританії - 2,2 млрд. євро, Франції - 351 млрд. євро, Польщі - 46 млрд. євро. Німеччини виділила з бюджету 50 млрд. євро, які спрямовані на виплату допомого підприємствам після виходу з карантину. Програма передбачає одноразову виплату у розмірі 9 тис. євро для підприємств з чисельністю персоналу не більше 5 осіб, 15 тис. євро - до 10 осіб та 25 тис. євро - більше ніж 10 осіб.

Що стосується України, то на підтримку найбільш вразливих суб'єктів господарювання, 3 бюджету коштів поки що не було виділено. Проте у березні Верховна Рада ухвалила законопроект, який надає підприємцям низку преференцій. Закон передбачає:

1) $з 1$ березня до 30 квітня 2020 року:

- звільнення від сплати ЄСВ всіх ФОПів, фрермерів та тих, хто займається незалежною професійною діяльністю (артисти, науковці, нотаріуси, адвокати);

- тимчасове скасування штрафів та пені за несвоєчасну або неповну сплату ЄСВ, а також за несвоєчасне подання звітності по ЄСВ;

- скасування податку на комерційну нерухомість та землю;

2) з 1 березня по 31 травня 2020 року:

- скасування штрафів та пені за порушення податкового законодавства (крім порушень по сплаті ПДВ, акцизів та ренти);

- мораторій на проведення документальних та фрактичних перевірок;

- відтермінування обов'язкового введення апаратів РРО (реєстрів розрахункових операцій; касовий апаратів, закон на які ввійшов у дію в березні 2020 року);

3) до 1 липня 2020 року продовжується термін подання річної декларації про майно та доходи, а суму нарахованих до сплати податків можна переказати до 1 жовтня 2020 року [8]. 
24 квітня 2020 року урядом було прийнято законопроект про соціальну допомогу на період карантину фрізичним особам-підприємцям, які мають дітей віком до 10 років.

Таку допомогу отримає близько 300 тис. сімей, у яких батьки ФОП належать до першої і другої групи платників єдиного податку та сплачували ЄСВ на період карантину та на один місяць після дати його відміни. Вона надаватиметься на кожну дитину у розмірі прожиткового мінімуму (для дітей віком до шести років -1 779 грн.; для дітей віком від шести до десяти років - 2218 грн.).

До того ж «ПриватБанк» ввів кредитні канікули своїм клієнтам малого та середнього бізнесу з 1 березня до кінця травня 2020 року, а «ПУМБ» відмінив сплату за проведення внутрішніх та зовнішніх платежів у національній валюті не весь період карантину.

Справжнім «рятувальним кругом» для українського бізнесу, після виходу з карантину, стане зниження облікової ставки. Правління Національного банку України 24 квітня 2020 року ухвалило рішення про зниження облікової ставки з 10\% до 8\% річних, що вплине і на зниження кредитної ставки комерційних банків.

Нині Верховна Рада розробляє програму дій, в якій будуть прописані шляхи підтримки бізнесу і тих, хто втратить роботу у зв'язку з коронавірусом. Поки що ведуться переговори з європейськими партнерами 3 підтримки МСП і з МВФ про підтримку української економіки.

Висновки. Необхідність державної підтримки малого та середнього підприємництва викликана тим, що, незважаючи на вагомі переваги малого та середнього бізнесу, саме цей сектор економіки найбільш вразливий до змін у як у політичному, так і у соціально-економічному житті суспільства (особливо це відчутно на прикладі України). Тому активна і цілеспрямована підтримка розвитку суб'єктів малого та середнього підприємництва сприяє зростанню ВВП та створенню нових робочих місць, що так буде необхідно в найближчому майбутньому.

\title{
Список використаних джерел
}

1. Біла І. С., Салатюк Н. М. Світовий досвід державного регулювання підприємництва. Проблеми економіки. 2014. № 1. С. 26-30.

2. Дергачова В. В., Колешня Я. О. Державна підтримка малого та середнього бізнесу в Україні. Науковий вісник Ужгородського національного університету. 2018. №20 (1). С. 130-133.

3. Поповенко Н. С., Ганенко О. В. Державна підтримка розвитку малого бізнесу в Україні. Економіка: реалії часу. 2012. № 1(2). С. 126-132.

4. Бізнес-схід «Уряд України виділив 2 млрд грн на нову бюджетну програму розвитку підприємництва». URL: https://bizshid.com/news/1647-uriad-ukrainy-vydilyv-2-mIrd-hrn-na-novu-biudzhetnu-prohramu-rozvytku-pidpryiemnytstva

5. Дмитро Андреєв «Державна політика з розвитку малого та середнього бізнесу інноваційного бізнесу в Україні». URL: https://ukrpatent.org/i_upload/file/wipo-seminar-10-2016/d1t02-2-Andreev.pdf

6. Офріційний портал Верховної Ради України. URL: https://rada.gov.uа

7. Офріційний сайт Державної служби статистики України. URL: http://www.ukrstat.gov.ua

8. «Карантинні пільги» для бізнесу: якою є справжня ціна перерви на пандемію. Українська правда інтернет-видання. URL: https://www.epravda.com.ua/publications/2020/03/18/658216/

\section{References}

1. Bila, I. S. \& Salatyuk, N. M. (2014). Svitovy ‘j dosvid derzhavnogo regulyuvannya pidpry`yemny 'cztva /World experience in business governance]. Problemy` ekonomiky - Economic problems, 1, 26-30 (in Ukr).

2. Dergachova, V. V. \& Koleshnya, Ya. O. (2018). Derzhavna pidtry`mka malogo ta seredn’ogo biznesu v Ukrayini [State support for small and medium-sized businesses in Ukraine]. Naukovy'j visny'k Uzhgorods'kogo nacional'nogo universy'tetu - Scientific Bulletin of Uzhgorod National University, 20 (1), 130-133 (in Ukr).

3. Popovenko, N. S. \& Ganenko, O. V. (2012). Derzhavna pidtry’mka rozvy'tku malogo biznesu v Ukrayini [State support for small business development in Ukraine]. Ekonomika: realiyi chasu - The economy: the realities of the times, 1(2), 126-132 (in Ukr).

4. The Government of Ukraine has allocated UAH 2 billion to the new Enterprise Development Budget Programme. URL: https://bizshid.com/news/1647-uriad-ukrainy-vydilyv-2-m/rd-hrn-na-novu-biudzhetnu-prohramurozvytku-pidpryiemnytstva

5. Andreyev, Dmy`tro (2016). Derzhavna polity’ka z rozvy`tku malogo ta seredn`ogo biznesu innovacijnogo biznesu $v$ Ukrayini [State policy for the development of small and medium-sized innovative business in Ukraine. URL: https://ukrpatent.org/i_upload/file/wipo-seminar-10-2016/d1t02-2-Andreev.pdf (in Ukr).

6. Official portal of the Supreme Council of Ukraine. URL: https://rada.gov.ua

7. Official website of the State Statistical Service of Ukraine. URL http://www.ukrstat.gov.ua

8. Karanty 'nni pil'gy' dlya biznesu: yakoyu ye spravzhnya cina perervy' na pandemiyu [Quarantine benefits for business: what is the real cost of a break on a pandemic] Ukrayins 'ka pravda - internet-vy dannya - Internet edition «Ukrainian Truth» URL: https://www.epravda.com.ua/publications/2020/03/18/658216/

\author{
ДАНІ ПРО АВТОРІВ \\ Нестерова Світлана Василівна, доцент \\ Мукачівський державний університет, \\ вул. Ужгородська, 26, м. Мукачево, 89608, Україна \\ e-mail: svnest7@gmail.com
}


orcid.org/0000-0002-7813-3378

Копча Вероніка Володимирівна, студентка

Мукачівський державний університет,

вул. Ужгородська, 26, м. Мукачево, 89608, Україна

e-mail: kopcaveronika@gmail.com

Михальчинець Галина Томівна, викладач

Мукачівський державний університет,

вул. Ужгородська, 26, м. Мукачево, 89608, Україна

e-mail: grv2006.12@gmail.com

\section{ДАННЫЕ ОБ АВТОРАХ}

Нестерова Светлана Васильевна, доцент

Мукачевский государственный университет,

ул. Ужгородская, 26, г. Мукачево, 89608, Украина

e-mail: svnest7@gmail.com

Копча Вероника Владимировна, студентка

Мукачевский государственный университет,

ул. Ужгородская, 26, г. Мукачево, 89608, Украина

e-mail: kopcaveronika@gmail.com

Михальчинец Галина Томовна, преподаватель Мукачевский государственный университет

ул. Ужгородская, 26, г. Мукачево, 89608, Украина

e-mail: grv2006.12@gmail.com

\section{DATA ABOUT THE AUTHORS}

Nesterova Svitlana, associate professor

Mukachevo State University,

str. Uzhgorods'ka, 26, Mukachevo, 89608, Ukraine

e-mail: svnest7@gmail.com

Kopcha Veronika, student

Mukachevo State University,

str. Uzhgorods`ka, 26, Mukachevo, 89608, Ukraine

e-mail: kopcaveronika@gmail.com

Myhalchinets Halyna, lecturer

Mukachevo State University,

str. Uzhgorods'ka, 26, Mukachevo, 89608, Ukraine

e-mail: grv2006.12@gmail.com

\section{РОЗВИТОК РИНКУ ЕЛЕКТРОННОЇ ТОРГІВЛІ В СВІТОВІЙ ЕКОНОМІЦІ ТА В МАКРОЕКОНОМІЧНИХ УМОВАХ УКРАЇНИ}

Тірбах Л. В.,

Чабан Г. В.

Актуальність теми дослідження. Дана стаття розкриває особливості розвитку ринку електронної торгівлі в світовій економіці та в Україні. Проведено аналіз стану ринку електронної торгівлі: виділені основні гравці ринку електронної торгівлі, проаналізовано обсяги продажів. Визначено, що електронна торгівля - це відносно новий вид економічної діяльності, який досить активно розвивається в Україні. Особливу увагу приділено структурі електронної торгівлі. Також окреслено проблеми і напрямки розвитку електронної торгівлі в Україні.

Постановка проблеми. Проблемою розвитку ринку електронної торгівлі в світовій економіці та в Україні є ї структура та нові напрями розвитку електронної торгівлі.

Аналіз останніх досліджень і публікацій, в яких започатковано розв'язання даної проблеми. Сучасний стан функціонування ринку електронної торгівлі в Україні за останні роки було досліджено у наукових працях Н. Апатова, Л. Гліненко, Ю. Дайновського, А. Маслов, С. Маловичко, О. Чубукова, P. Царьов та ін. У працях вітчизняних вчених питання аналізу ринкових тенденцій електронного ринку розглядаються недостатньо глибоко. Ця проблема вимагає дослідження і впливає на розвиток відносин на Українському ринку електронної торгівлі. 